\title{
機械学習研究におけるプログラム開発と検証
}

モンテカルロ法に基づく確率推論計算を例として

\section{Software Development and Testing for Machine Learning Studies}

With an Example of Probabilistic Inference with Monte Carlo Based Methods

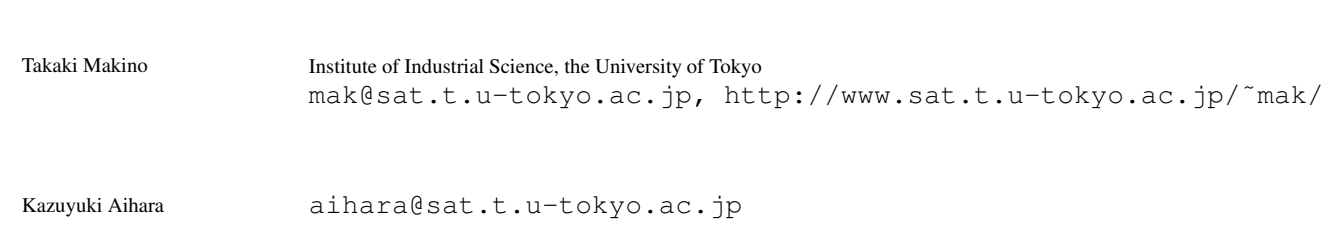

keywords: Monte Carlo methods, machine learning, program development, validation, statistical inference

\section{Summary}

It is not easy to test software used in studies of machine learning with statistical frameworks. In particular, software for randomized algorithms such as Monte Carlo methods compromises testing process. Combined with underestimation of the importance of software testing in academic fields, many software programs without appropriate validation are being used and causing problems. In this article, we discuss the importance of writing test codes for software used in research, and present a practical way for testing, focusing on programs using Monte Carlo methods.

\section{1. ま え がき}

データの背後にある法則性を発見し，適切な予測を実 現するための手法として , 統計的手法に基づく機械学習 技術の研究が盛んになっている. 炎の理由の一つとして， これまでのさまざまな手法を統一的に理解する理論的バッ クグラウンドとしての統計理論の重要性が再認識されて きたという経緯がある [Bishop 07] . ヒューリスティクス に基づいて開発された精度の高い手法が, 統計モデルと して説明ができるといった研究 [Teh 06a] もあり, 研究 が活発化している.計算機パワーの増大に伴い，はじめ から統計モデルの形で学習手法を定義し, 確率推論の形 で直接解く方法が，実用的になりつつある .

このような学習手法を実現するために欠かせないのが， 正確な確率推論プログラムの開発である . 特に, ベイズ 統計に基づく推論の場合には, 問題に合わせたモデルを 構築し推論する必要があることから, パッケージ化され たプログラムやライブラリを利用するだけでは必要な計 算が行えない場合が多い．新たな確率モデルの提案や機 械学習技術を応用した AI システムの構築といった，機 械学習に関する研究を行う樣々な場面で, 必要な確率推 論を行うプログラムを開発して利用する必要が生じる .

しかし現実には, プログラムの正確性が確認されない まま，使われてしまう場合が少なくないように思われる． もちろん, プログラムの誤りはどの分野の研究でも起こ りうることであるが, 特に確率推論にかかわるプログラ
ムの場合 , 顕在化しない誤りによって致命的な差が生じ ることが起こりうる．

兴の最大の理由は, 確率推論に関するプログラムでは, 正確性の検証が困難なことである.特に，マルコフ連鎖 モンテカルロ (MCMC) 法 [伊庭 05] のような乱択アルゴ リズムによる確率推論の場合には, プログラムが動作し て何らかの結果が得られても，弚れが正しい結果かどう かを直接確かめることはできない．一般的な数值計算で 行われるような, 収束の安定性や理論值との誤差の評価 などから , プログラムの正確性をある程度確認するといっ たことも難しい，乥の結果，「なんとなく大丈夫炎うな」 (実際にはほとんど検証されていない) プログラムが使わ れてしまう可能性が，他分野に比べて高いと思われる .

本稿では, 特に乱択アルゴリズムに基づく確率推論プ ログラムに焦点をあてて, 研究ソフトウェア開発におけ る検証の必要性を述べ, 確率推論プログラムに対して有 効な検証手法として筆者らが実践しているものをいくつ か紹介する．図1に，本論文において取り扱う問題と対 策の範囲を示す . 本稿が , 機械学習の研究を進める上で のノウハウとして , 何らかの参考になれば幸いである .

\section{2. 機械学習と確率推論}

機械学習とは,与えられたデータから，隠れたパターン を発見する手法である [Bishop 07] .もつとも簡単な教師つ き学習の枠組みでは, 未知の関係で結びつけられた入力 $\mathrm{x}$ 
発生する問題
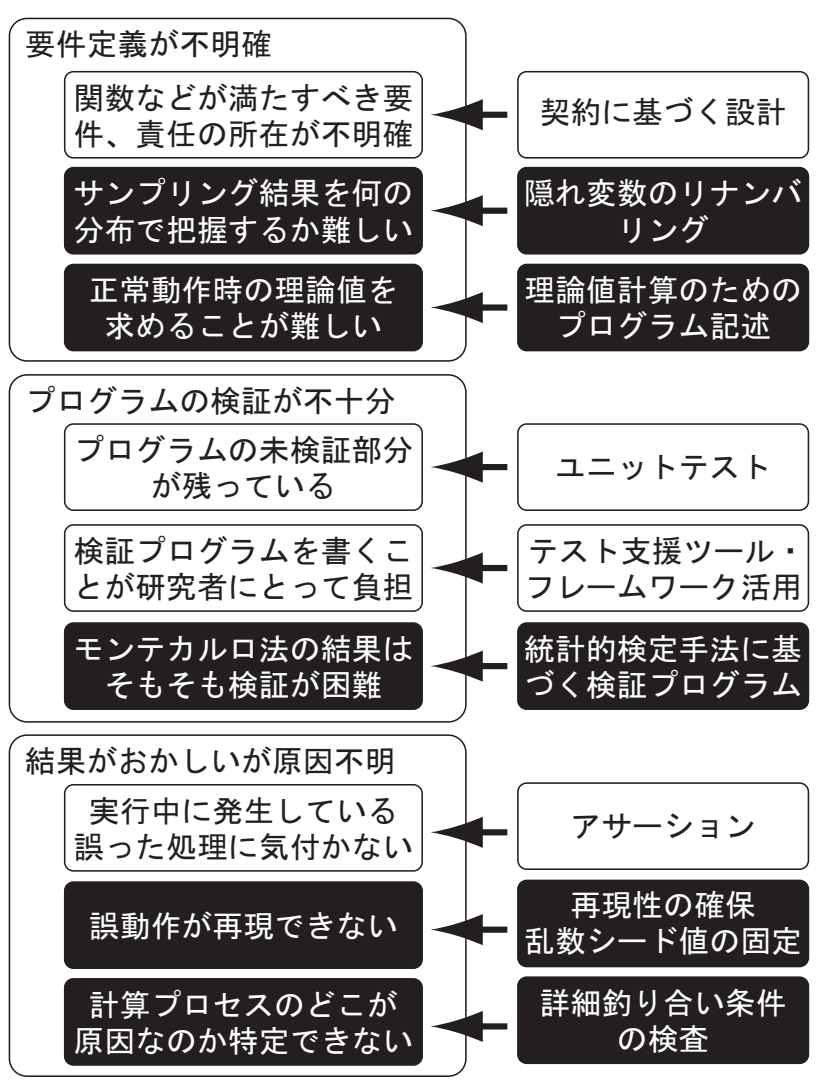

修正中に別の問題を混入させる

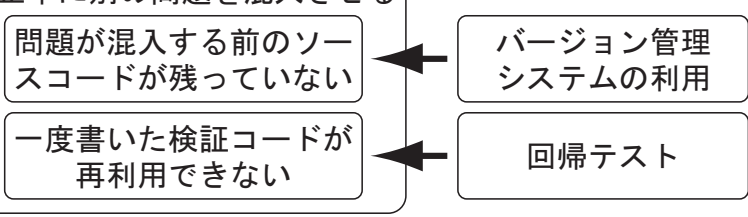

図 1 本稿て扱う, 研究ソフトウェア開発において発生する問題と 対策 . 黑地に白文字は, 確率推論プログラム特有の要素

と出力 $y$ の $n$ 組の教師データ $D=\left\{\left(\mathbf{x}_{1}, y_{1}\right), \ldots,\left(\mathbf{x}_{n}, y_{n}\right)\right\}$ が与えられているときに , テスト入力 $\mathrm{x}_{n+1}$ にはどのよ うな出力 $y_{n+1}$ が対応するかを予測するような問題を取 り扱うもので, 樣々な手法が提案されてきた。

たとえば, 線形回帰モデルは, 入力から計算される基 底関数のベクトル $\phi(\mathbf{x})($ 与えられるものとする) をもと に，線形の識別モデル $y(\mathbf{x})=\mathbf{w}^{T} \phi(\mathbf{x})$ を考え，パラメー 夕 $\mathrm{w}$ を調節することで, 教師データに含まれる規則性 を再現することを目指すものである.単純には，線形回 帰モデルのパラメータ $\mathrm{w}$ は最小 2 乗法によって決定す ることができる．しかし，基底関数の次元が多い場合に は, ノイズに対して過剩にパラメータが変動してしまう ため, テスト入力に対して適切な答えを出すことが難し い(過学習).一方, 基底関数の次元が少ないとモデルの 表現能力が制限されてしまう. 基底関数の次元数を調節 したり, パラメータの変動にペナルティを科す正則化項 を導入するといった手法もあるが，交差確認等の手法で は勾配法が使えないこともあり, 次元数, 正則化項など
のハイパーパラメータは, 数が多い場合には決定が困難 になる . また，得られた予測值の確からしさを評価する ことができないため，予測に基づく決定のコストなど最 適化する対象が変わるたびに, パラメータ決定をし直す 必要があった .

このような問題に対して,近年, 統計学の考え方を導入 することで, 問題と解決法の統一的な理解が実現できる ことがわかってきた .たとえば, 線形回帰モデルにおける パラメータは,データを見る前であっても，極端に大きな 值は取りにくいという事前知識が存在する [Bishop 07] . ある仮説の確からしさを表現する道具として確率を導入 するベイズ統計の枠組みに基づいて, 事前知識をパラメー 夕空間上の確率分布 $p(\mathbf{w})$ の形で事前分布として表現し， 弚のパラメータからデータが観測される尤度 $p(D \mid \mathbf{w})$ も 確率表現で与えることで, ベイズの定理により, データ 観測後のパラメータの事後確率分布 $p(\mathbf{w} \mid D)$ が得られる . 実際, 事前分布 $p(\mathbf{w})$ をガウス分布で与え, ノイズを含 む観測モデルを考えた場合の最大事後確率 (MAP) 解は， 2 次の正則化項を与えた最小 2 乗法と等価になることが 知られている [Bishop 07] . 弚れだけでなく, パラメータ $\mathrm{w}$ を積分消去することで, テストデータに対する答えの 予測分布 $p\left(y_{n+1} \mid D, \mathbf{x}_{n+1}\right)$ (すなわち，予測值の確から しさ)や，コストの期待値を評価できるなど，確率論の 枠組みを使うことで，これまでのモデルの応用が格段に 広がるのである.さらに, 基底関数の次元数などのハイ パーパラメータの良さをエビデンス (ハイパーパラメー タが与えられた時のデータ尤度)の形で表現できるので， 多数のハイパーパラメータもエビデンス最適化によって 決定できるし (経験ベイズ)，階層ベイズやノンパラメト リックベイズ手法などの最新の統計的枠組みを適用する ことで，ハイパーパラメータにも事前分布を考え，積分 消去することができるようになってきている [Hjort 10] . 適切な生成モデルを用意し, 正しい確率推論に基づいて 分布を求めることで, 従来よりもよい精度の予測が得ら れ, 兴の理由も理論的に説明できることが多いため, 機 械学習の領域では確率推論に基づいた研究か増えてきて いる。

しかし，実用的なモデルの多くは外部から観測できな い潜在変数を含むため, パラメータの事後分布や予測分 布は複雑な形状になり，解析的に解くことができない．こ のような場合には，適切な確率推論の近似解法を用いて， 問題を解くことが必要になる.ベイズ推定に対する近似 解法としては, マルコフ連鎖モンテカルロ (MCMC) 法 を代表とするサンプリング法が代表的である. 求めたい 分布中の点 (サンプル) を, 独立同分布で多数収集するこ とで, 必要な積分計算を近似することができる.プログ ラムが比較的シンプルになり，サンプルの数さえあれば いくらでも近似を良くすることができるため，モデルの 性能を評価する場面で多く用いられる．また，変分ベイ ズ法と呼ばれる，解析的に記述できる関数族を与えて近 
似し，近似誤差を KL ダイバージェンスで評価して変分 法で最小化する手法も，近似誤差が残るものの, 計算を 高速にできることから，より現実的な規模の問題にも適 用できるという利点があり, 近年, 樣々なモデルに対す る変分ベイズ解法が提案されてきている .

いずれにしろ, 確率に基づく手法の要となるのは, 正 確な確率推論である.しかし, 解きたいモデルごとに必 要な推論の仕組みが異なるため, ライブラリなどですべ て解決するというのは難しく, 構成部品としてライブラ リを利用するとしても，一般的には，推論プログラムは 解きたい対象のモデルに合わせてテーラーメードに開発 する必要がある．

\section{3. 研究におけるソフトゥェア検証の重要性}

上記のような議論をもとに，研究計画を立てようとす ると，理論的な美しさ，一見したプログラムの単純さか ら，コーディングから実験までの期間を過少に見積もり がちである . 例えば, サンプリング法はプログラムがシ ンプルなので, プログラムが完成し，ひととおり動作す るようになれば実験ができると考えて計画を立てたもの の, プログラムが実験中に次々とおかしな振る舞いを示 し，解決するために予想以上の時間を費やしてしまう，と いう事例は多い。

このような問題が生じる原因として, 研究レベルのプ ログラム開発において, 開発したプログラムを検証する ことの重要性が過小評価されていることを指摘したい .

通常の研究フローのよくあるパターンは, モデルに対 応するプログラムをコーディングして，簡単なデータで実 行させ, エラーにならずにおおむね期待通りの結果が出 ればプログラム完了, 締切も迫っているので多少のチュー ンをしつつ大規模実験に移る，なにか問題が起きれば先 の都度対応，というものである.しかし、「おおむね期待 に沿った結果を出す」プログラムと,「正しい」ブログラ ムとの間に実は大きな間隙が広がっており，実は正しく ないプログラムのまま実験してしまっている例も少なく ないと思われる . また , 大規模実験においてプログラム を修正しているうちに, いつのまにか根本的な間違いを 混入させてしまう，などといった問題も発生する .

そして, 特にこのようなアプローチが問題になる典型 例が , サンプリング法を含む乱択アルゴリズムを利用し た研究である.理由は単純で, 乱数で動作するため「お おむね期待に沿った結果」の範囲が広すぎるからである． また，ほかの計算法で利用できる簡単な検算法 (たとえ ば, 反復演算における值—变分ベイズであれば变分下 限—の収束の確認など) か利用できないため, 計算上の 樣々な問題が含まれていても気づかないことが多い. 光 して，弚のようなプログラムを大規模なデータに適用し て良い結果が出ない場合に, 何が原因なのか分からなく なってしまうことになる .
このような問題を回避するためには, 特に機械学習な どの数值計算に関する研究をする場合には, プログラム 開発から実験の間に検証の手順を踏むことを，研究計画 の段階から入れておくことが必要である.当然のことで あるが, たとえ自分しか使わないプログラムであっても， 正しいかどうか確認できないプログラムに基づいた研究 をすべきではない .特に, モンテカルロ法など乱択アルゴ リズムに属する手法を使う場合には , 見かけの簡単さに 惑わされずに，十分な検証を実施することが肝要である .

\section{4. 一般的なソフトゥェア検証手法}

ソフトウェア開発における検証手法に関しては, 専門 家によって書かれた本が多数あるので, 光ちらを参照さ れたい(たとえば [Myers 11]).しかし，以下での議論で 必要なため,ここで簡単に，一般的なソフトウェア開発 における検証手法を紹介する．

テストとは,「エラーをみつけるつもりでプログラムを 実行する過程」である [Myers 11] . 具体的には , プログ ラムに用意した入力を与えた時に, 出力が期待される結 果と一致するかどうかを調べることになる.一番簡単に 実施できるテストは，乥の場で入力を用意し，実行結果 を目視で確認する，いわゆる手動テストであるが , テス 卜の回数だけ手間がかかり，煩雑であるため，コードの 変更が困難になる．また，テストの網羅性・一貫性を保 つことか難しく，結果的に欠陥を見落とすことも多い．

この問題を解決するには, テストのためのプログラム （テストコード）を用意し，テストを自動化することが有 効である [Feathers 04] .一般に，次のような考え方に基 づいて検証を実施することが有効であるとされている． i. テスト対象とは独立にテストコードを書く(ブラック ボックステスト)

テスト対象となるコードとは独立に，弚のコードが満 たすべき条件 (入力に対して期待される出力) を検査する コードを書くことで, コード記述時には気付かなかった 問題を発見することができる [Beizer 95] . テストコード とはプログラミング言語で書いたプログラムの仕樣書で ある，と考えてもよい．すべての入力の組み合わせに対 してテストを実施するのは不可能だが , 効率のよいテス トのために，代表的な要素を選ぶ樣々なヒューリスティ クスが知られている [Myers 11, 第4 章] (振る舞いの異な る代表例, 入力範囲の境界值, 境界外の值, ゼロなど) . ii. テストコードはすべてとっておき, まとめて再実行 できるようにしておく (回帰テスト)

テストは一回だけ走らせればよいというものではない . 一度修正した問題が，他の部分の修正に伴って再発する ことは多く，多くの時間をロスする原因になる . テスト コードはできるだけ使い捨てにせず , プログラムに修正 を加えるたびに繰り返し実行できるよう，実験プログラ ムとは独立してテストを用意し，必要に応じていつでも， 
また，すべてのテストを自動的に実行できるようなテス トコードを用意することが望ましい [Panzl 78] しかし， 回帰テストが増えすぎると，テストにかかる時間が長く なりすぎるという問題もある [Engström 10].研究て記述 する規模のソフトウェアでは, 何を回帰テストとして残 しておくかは, 開発者の視点で決めることになるだろう . iii. プログラムの各部分を独立にテストする (ユニット テスト)

プログラム全体の動作をテストすることも必要だが， 弚れだけではプログラム中でテストされていない部分が 残ることが往々にしてある.こうしたテスト漏れをなく すためには, 機能単位 (サブルーチン, クラスなど) ごと にテストを割り当て , 各機能単位を十分にテストするこ とが有効であるとされている [Koskela 12] . テストカバ レッジ(テストで実行されたソースコードの部分) を調ベ ることで, テスト漏れを発見する助けとすることもでき るが, 重要なのは機能単位ごとに満たすべき入出力の仕 樣が存在し，弚の仕樣を適切に確認するテストか設計さ れることである．弚のための考え方として，先にテスト コードを書いて機能単位が満たすべき仕樣を確定し，光 の後にプログラムを書くという方法も提案されている(テ ス卜駆動/ビヘイビア駆動開発) [Beck 02, Chelimsky 10] . iv. 機能単位の責任を明確化する (Design by contract, 契約による設計)

サブルーチンの仕樣を明確化し, 設計の安全性を高め る方法として, 呼び出し行為を呼ぶ側と呼び出される側 との契約として捉える考え方がある [McKim 01] . 契約 が満たされるための条件として , サブルーチンの入り口 で守られるべき条件 (事前条件)，出口で守られるべき条 件 (事後条件) を考える.サブルーチンを呼心測は事前条 件を満たす義務を負う代わりに，呼び出し後に事後条件 が満たされるという利益を得る.呼び出される側は，事 前条件を前提とできるという利益を得る代わりに，終了 時に事後条件を満たすという義務を負う．このようにす ることで, 呼び出されるサブルーチンの側に誤りがある 場合と，サブルーチンを呼心゙側に誤りがある場合を明確 に区別できるようになる .

さらに , オブジェクト指向に基づくプログラムの場合 には ,データ構造に対しても同樣の手法が適用できる.オ ブジェクトが操作前後で保持しているべき条件 (不変条 件)を考え , 公開メンハ関数の開始・終了時には必ず不変 条件が満たされると考えることで, オブジェクトに対す る誤操作の責任の所在も明確化できる .

v. プログラムの実行時にもテストするコードを埋め込 む (アサーション)

契約による設計などの形で , プログラムの途中で常に 満たされるべき条件が明確になっている場合には，実行 時に条件が破られていないかを検査することで, 問題を 早期に発見できる [Hoare 69] . 契約による設計を概念と して含むプログラミング言語もあるが [Meyer 91] , 通常
表 1 研究でよく使われる言語でのユニットテストフレームワーク

JUnit (Java) Java 言語上ではもつともよく利用されている テストフレームワーク.他の多くの言語のテストフレー ムワーク (xTest) の原形にもなっている

Boost::Test (C++) テストの追加が簡単であり，研究環境で あれば十分な機能を提供している. Boost は他にも実用 的な乱数生成器, カイ 2 乗分布を含む統計関数など, 樣々 なライブラリを提供しており，C++ で研究する人は知っ ておいて損はない .

Test::More (Perl) 古くからある Perl 上のテスト環境 .

unittest (Python) Python 2.1 以降で標準サポート

RUnit (R) R 言語上でのユニットテストフレームワーク

MATLAB xUnit (MATLAB) MATLAB 上でのユニットテ ストフレームワーク

のプログラミング言語でもアサーション構文 $(\mathrm{C} / \mathrm{C}++$ の assert() マクロ , Java の assert 文など) を利用することで， テスト中だけでなく，実行時に常に条件を検査すること が可能である [Rogers 01] .たとえば，必ず非零の確率値 $\mathrm{p}$ が渡されるという事前条件の関数であれば, assert $(0<\mathrm{p} \& \& \mathrm{p}<=1)$ のように引数を検査することで, 呼 び出し元に稀な誤り (例えば，確率値のアンダーフロー) があった場合に，問題を早期に発見し，光の場所を特定 することが可能になる . 同樣に , 事後条件・オブジェク 卜不変条件に関するアサーションを記述することで, サ ブルーチンやメンバ関数の誤りを発見できる. 契約条件 に限らず，ループ不変条件, 計算の中間值が満たす条件 なども検査対象になる .

ブラックボックステストをプログラムの外形的な検証 であるとすると，アサーションは内部からの検証に相当 し , 組み合わせることでより厳密なプログラム検証が可 能になる.アサーションは, コンパイルオプション等で 処理しないようにできるので, 大規模データに対する実 験時などに効率を落とすこともない(しかしながら，稀な 問題を見逃さないためには, 大規模データに対しても一 度はアサーション有効のまま実行してみるべきである）． vi. 開発の各段階を保存しておく (バージョン管理)

開発においてソースコードを変更していく履歴を残す ことで, 問題が発生したときに, いつから問題が発生し たのかといったことを調べ, 修正することが容易になる [Spinellis 05] . 時々ソースコードをディレクトリごと圧縮 しておくという程度でもよいが，ここでは Subversion*1 や git ${ }^{* 2}$, Team Foundation Server (Microsoft)などのバー ジョン管理システムの利用を勧めたい，一般に,バージョ ン管理システムは, 複数人で開発するときのコード共有 ッールであると思われることが多いが , 1 人での開発で も有効である . 実験時にリビジョンを確定させておくこ とで, 変更点を後から確認することが容易になる．また， 異なる環境 (大学のデスクトップと計算機センター, 自 宅のノート PC など) でのソースコードの同期が容易にな り，バックアップも同時に取れる，等のメリットもある .

*1 http://subversion.tigris.org/

*2 http://git-scm.com/ 


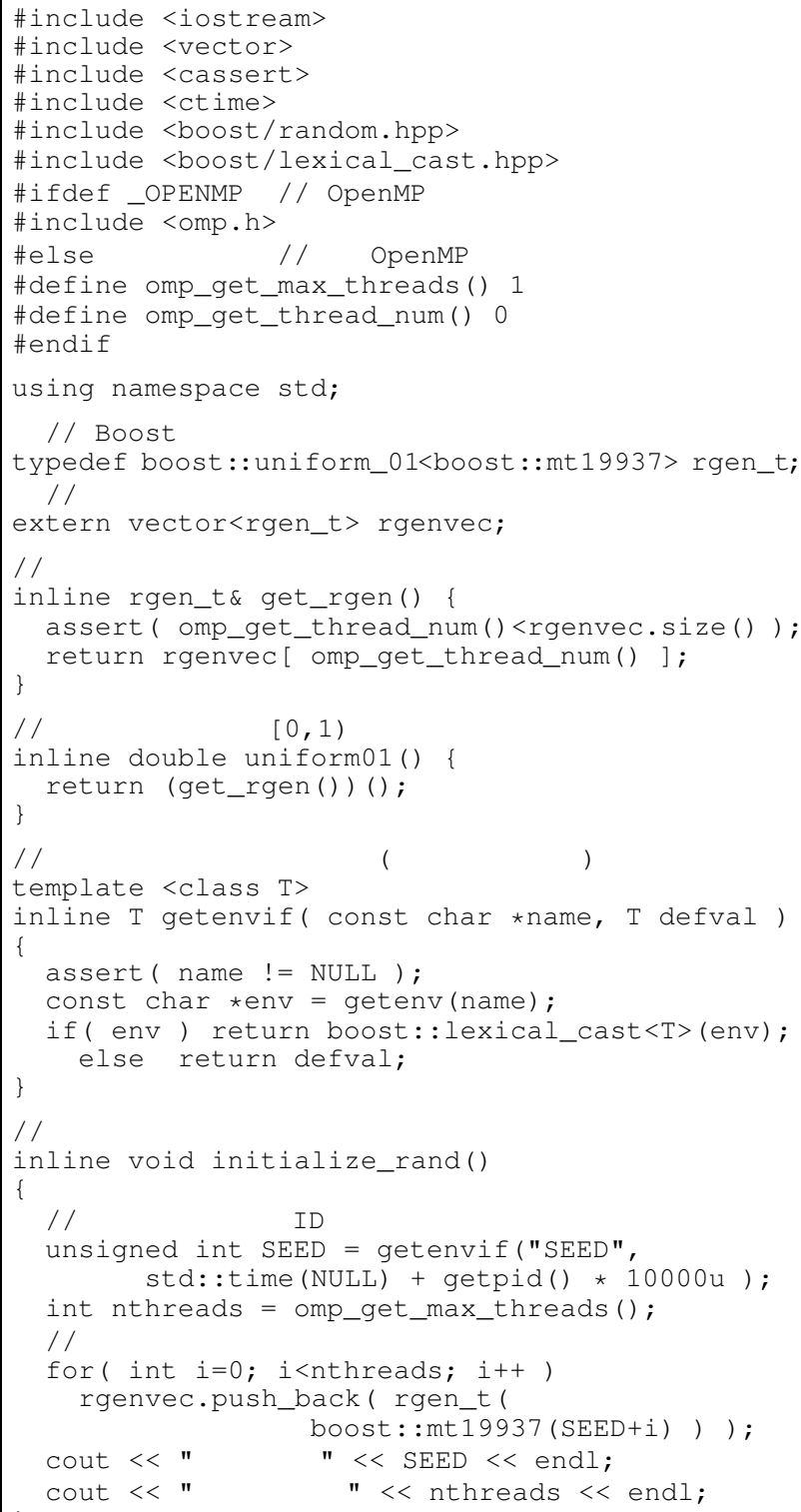

\section{/ 乱数生成器の初期化関数}

inline void initialize rand()

// 時刻とプロセス ID からシード值を合成

unsigned int SEED = getenvif("SEED", std: :time (NULL) + getpid() * 10000u );

int nthreads = omp_get_max_threads ();

// 各スレッド用の乱数生成器を準備

for ( int $i=0$; $i<$ nthreads; $i++$ )

rgenvec.push_back(rgen_t( boost: : mt19937(SEED+i) ) )i

cout $<<$ "シード值 " < SEED < endl;

cout $<<$ "スレツド数 " < nthreads < endl;

図 2 omprand.h: C++で OpenMP 使用時に，各スレッド毎に乱 数生成器を持たせるコードの例

テストコードの記述はストレスのたまる作業であるが， テストの開発および自動化を支援するためのフレームワー クとして，多種多樣なライブラリが提供されており，光 れらを使うことで負担はかなり軽減される.特に, ユニッ トテストに関するものは個人でも使いやすいものが多く， 表 1 で示す例のほかにも，現在利用可能なプログラミン グ言語のほぼすべてで樣々なテスト環境が提供されてい る.また，Eclipse，Visual Studio などの最近の統合開発 環境では, テスト関連を含めた樣々な機能が組み込み・プ ラグイン形式で提供されており，マウスでクリックする だけでテストコードのひな形生成やテストカバレッジの 表示 (Visual Studio 2008 では Professional Edition 以上)， バージョン管理システムとの同期などが実現できる .こ れらの環境を利用して開発しているのであれば，これら の支援機能についても調べてみる価值はあると思われる．

\section{5. モンテカルロ法の計算プログラムに対する 検証技術}

どのようなプログラムでも適切に検証することは容易 ではないのだが , モンテカルロ法などの乱択アルゴリズ ムは段違いに検証が難しい，弚の理由として次の 2 点が 挙げられる . (1) 異常があった場合に, 現象の再現が困難 . (2) 乱数に基づく結果の検証兴のものが簡単ではない .

以下では, これらの問題を解決する方法について , モン テカルロ法に基づくプログラムを念頭に置いて説明する .

\section{$5 \cdot 1$ 再現性のある実行環境の確保}

アサーションでの異常検出，ゼロ除算，メモリ管理の 問題など , 明らかなプログラムの実行エラーが発生した 場合でも，光の事象を再現できなければ, プログラムの 修正は困難である . 通常のプログラムであれば , 同じ入 力を与えることで問題を再現できることが多いが, 乱数 で動作するプログラムの場合，実行毎に異なる乱数値が 得られると, 問題が再現しない場合が多い.

兴のような場合に有効な手法として，擬似乱数のシー ド值の固定がある . シード值を固定することで , 毎回同 じ乱数列が与えられることが保証できるので, 計算過程 を何回も再現できるようになり，異常な值がどこから来 たかを調べることか可能になる．実験時にはシード值を 変えて何度か実行することになる*3 が, 弚の場合でも，利 用したシード值を実験結果とともに保存しておくのがよ い. 大規模実験時に問題が発生した場合，同じシード值・ 同じ入力データで assert を有効にしたプログラムを実行 することで，問題を特定できる場合がある．

ただし，並列計算を利用している場合などでは，乱数 関数の呼び出し順序が毎回変わってしまうため, シード 值を単純に固定する方法がうまくいかないことがある． 兴のような場合, まず, 乱数生成器のインスタンスをス レッド毎に持たせることを検討すべきである . そも光も 通常の乱数生成関数は再入可能ではないので，内部で排 他ロック制御を行っている. 乱数生成器のインスタンス をスレッド毎に持たせると，排他ロックの待ち時間が不 要になり，プログラムの実行効率も上昇する*4 . 延のう

*3 検証技術からは外れた話になるが , シード值を作るときに time () 関数などのシステム時刻の值を使う慣習があるが, 特 に最近のマルチコア環境では, 同じ時刻に複数のジョブか実行さ れると,すべてのジョブで同じシード値が使われてしまう危険性 がある.時刻だけでなく , プロセス ID などのジョブ毎に異なる 数值と組み合わせるか, UNIX 系 OS であれば/dev/random などのシステムが提供する擬似乱数発生器を利用したシード值 の設定を検討すべきである

*4 厳密を期す場合, 複数の生成器で乱数が同期してしまう問題 を避けるために, 多ストリーム対応が保証された乱数生成器を 利用することか望ましい(例えば [Mascagni 00])が，これらの 公開ライブラリで生成できるのは一樣乱数に限られ, 研究の場 面においては使いにくい.複数インスタンスの乱数生成器を使 うことには同樣の保証はないが , メルセンヌツイスタ等の高品 質で長周期の乱数生成器を異なるシード值で初期化することは， jump-ahead 法 [Haramoto 08] の近似とみなすことができ，機械 


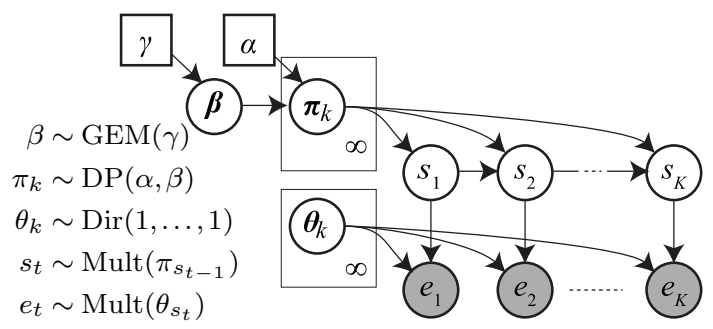

図 3 infinite HMM の定義とグラフィカルモデル .

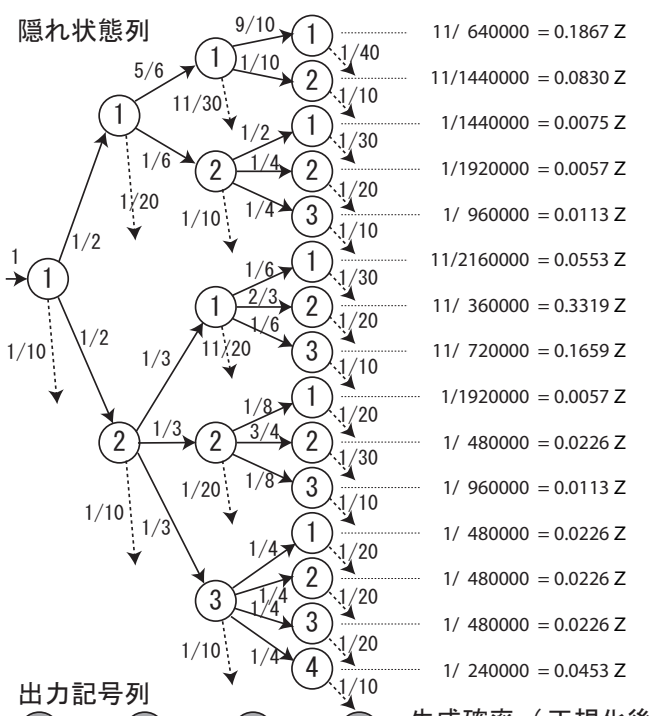

(A) (B) (A) 生成確率（正規化後)

図 4 iHMM において出力列 ABAC に対する隠れ状態列の理論分 布の例 . 円内の数字はリナンバリングされた隠れ状態, 実線 矢印は状態発展, 破線矢印は出力, 矢印に付加された数值は 生成確率の期待値を表わす。確率分岐に沿って期待值の積を 取ると生成確率の理論分布が得られ，生成確率の和 $Z$ で正規 化することで出力列観測後の事後分布か計算できる . 確率値 の計算においては, 出力記号は 10 種類, $\gamma=\alpha=1$ とした .

えで, 各スレッドへのジョブ配分・結果の統合順序を静 的に決定しておくことで, 並列計算環境でも結果を再現 可能にすることはできる (図 2) ${ }^{* 5}$.

\section{$5 \cdot 2$ モンテカルロ法の結果に対する検証}

機械学習などの数值計算を含むプログラムの場合には， 各部分をテストするコードに加え, 記述したアルゴリズ ムが予想通りの答えを返すかどうかを調べることが必要 である.具体的には, 非常に小規模なデータに対して理 論值を導出し，プログラムを実行した結果と等しくなる かどうかを確認することである . 大規模なデータに対す

学習のような場面では許容できる方法であると考えている . 低 品質の擬似乱数 (C 言語標準の rand() 関数など) は, 並列化し ない場合でも，乱択アルゴリズムの研究に使うべきではない， *5 とはいえ, 決して並列処理の導入を推奨するわけではない. むやみに並列処理を導入すると, 並列処理特有の問題が発生し たり, 計算順序の変化により確率的に不正確な推論になる可能 性もあるため,どうしても必要な場合以外は並列化すべきでな い.ややむなく並列化する場合は，並列化する領域を慎重に検討 することに加え，十分なテストを実施することが肝要である
る結果に問題がある際に原因をたどることは難しいが， 小規模な問題であれば，理論值の導出過程との比較をす るなどの方法で , 問題を同定することが可能である .

しかし，MCMC 法などの乱数を含むアルゴリズムの 場合，ある時点でのサンプリング結果に対してこのよう な検証をすることはできない，光も光も，乱数での出力 であるため，多くの值か理論的にありえる值となり，実 質的な検査ができない .

本来 , モンテカルロ法は, サンプル分布が求めたい確 率分布になっているというものであり， テストコードも この性質をテストすべきである．言い換えると，モンテ カルロ法のテストコードは, サンプリングされた結果を 収集して何らかの特徵に関する経験分布を作り，統計的 検定手法に基づいて理論分布と比較する必要がある．

ここで, どの特徵を対象にすべきかは, 問題の性質に 依存するものであり，簡単には決められない，例として， 筆者らが取り組んだHMM の問題の例を挙げる. 研究の 対象は, infinite HMM [Beal 02, Teh 06b] と呼ばれる隠 れ状態数についても統計的に決定する HMM のノンパラ メトリックベイズ拡張モデルである (図 3). 与えられた 観測列に対する事後分布を推定するためには，噯れ状態 列の事後分布と遷移行列 - 出力行列の事後分布を同時に 推定する必要があるため，筆者らは MCMC 法を適用し， 隠れ状態列と遷移行列・出力行列を交互にサンプリング するプログラムを開発した .このプログラムのテストの ために，非常に短い観測列 (ここでは 4 ステップ)に対す るサンプリング結果の分布を検証する．

この場合 , サンプリングされた隠れ状態のラベルの分 布を作っても，隠れ状態のラベルは交換可能なので, 意 味のある分布は得られない . もう少しよいのは, サンプ ルにおける隠れ状態列の中で使われている隠れ状態の異 なり数 (重複排除後の個数) を考えることである. 特に， infinite HMM においては, 隠れ状態数についてもデータ から統計的に決定する枠組みであるので, 弚の分布につ いては確認しておきたい．しかし，4 ステップの入力に おいては, 利用される隠れ状態数は高々 4 個であり，サ ンプリングされる隠れ状態列の分類としては荒い . この ような分類の上では, 分布の違いは検出できるが検出力 が弱く, また違いがあると分かった場合にも, 問題を追 跡するのが困難である .

最終的にテストに利用したのは, 隠れ状態を登場順に $1,2,3, \cdots$ とリナンバリングした結果の隠れ状態列であ る「1111」は4 ステップすべて同じ隠れ状態としてサン プリングされたことを示し, $1223 」$ は, 2 ステップ目と 3 ステップ目だけが同じ隠れ状態で, 弚の他は異なる隠 れ状態としてサンプリングされたことに対応する .これ により，ラベルの交換可能性の問題を回避しつつ，15 項 からなる離散分布を得ることができる (図 4).この分布 の理論分布を計算し (具体的方法は後述), サンプリング 分布を検定することで, サンプリングプログラムの間違 


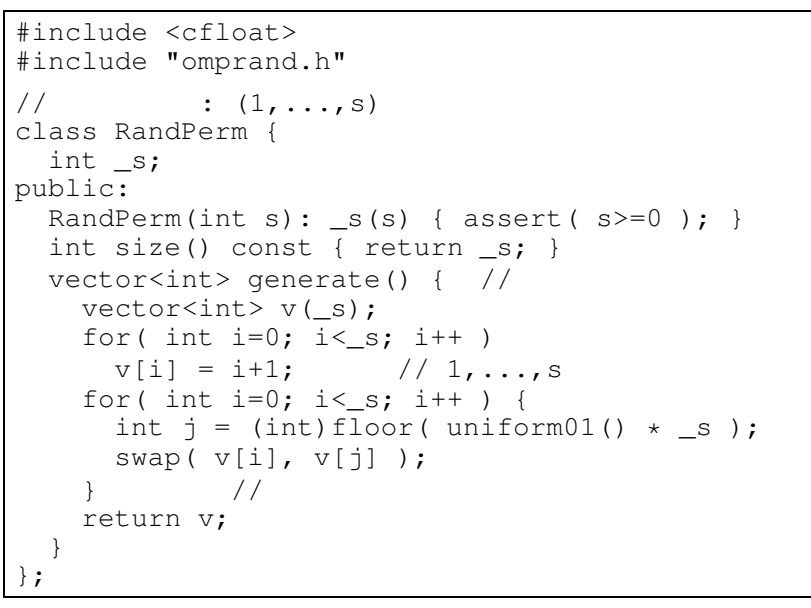

図 5 perm.h: テスト対象となる (誤った) C++ コード.

いを検出し，問題を修正することが可能になった． ここで解説したリナンバリングによる交換可能性の回 避は, iHMM だけでなく, LDA [Blei 03]などの交換可能 な隠れ変数を含むモデルであれば同樣に適用可能である .

\section{$5 \cdot 3$ 統計的検定手法に基づくサンプル分布の検定}

正しいサンプリング法であっても，経験分布と理論分 布の間にはズレが残る.サンプル数を増やしていけば理 論分布にどんどん近付くはずではあるが，どのような結 果であれば , 現在のプログラムは正しいサンプリングを しているといえるだろうか .これは，いわゆる古典的統 計学における検定の問題である . テストを実施するため には, 適切な検定法を選び, 検定を行うプログラムを書 かなければならない .どの検定法を使うかを選べなけれ ば，統計計算のライブラリを使うことも難しい．

特にサンプリングに基づく研究を行うのであれば, 基 本的な検定方法について, 統計学の基礎 (例えば [東京 92]）に立脚することが大切である . たとえば , 今回のよ うにサンプル数に制限がない場合では, ピアソンのカイ 2 乗検定が比較的使いやすい, 以下では, カイ 2 乗検定 を使った検証法を紹介する．

観測ごとに $K$ 個の排他的事象 $\{1,2, \ldots, K\}$ の 1 つが 観測される場合に，カイ 2 乗検定においては,「観察され た事象の相対的頻度がある頻度分布 $p_{k}$ に従う」という 帰無仮説を検定する.$N$ 回の観測を繰り返して事象 $k$ が $O_{k}$ 回観察されたとき, 帰無仮説が成り立つ場合は, 各事 象の期待観測回数 $E_{k}=N \cdot p_{k}$ に基づくカイ 2 乗統計量 $\chi^{2}=\sum_{k=1}^{K}\left(O_{k}-E_{k}\right)^{2} / E_{k}$ は自由度 $K-1$ のカイ 2 乗 分布に従う . 通常の検定においては，有意水準をあらか じめ定める $(\mathrm{p}=0.01$ など $)$ こで, カイ 2 乗の水準値を 決めることが可能になる.すなわち, 計算されたカイ 2 乗値が兴の水準を上回るときには，帰無仮説が稁却され， 「観測した分布は期待分布と有意に異なる」，すなわちプ ログラムが間違っているという結論が示唆される.一方， カイ 2 乗値が水準値を下回る場合は, 「観測した分布は期 \#include <unistd.h>

\#include <boost/math/distributions/chi_squared.hpp \#include "perm.h"

\#define BOOST TEST DYN LINK

\#define BOOST_TEST_NO_MAIN

\#include <boost/test/unit_test.hpp>

// 乱数生成器の配列の実体定義 (図 2)

vector<rgen_t> rgenvec;

// PermRand (sz) の $\mathrm{k}$ 番目の值の分布をテストする関数

void TestPerm( int sz, int $\mathrm{k}$ )

\{

$\operatorname{assert}(\mathrm{sz}>\mathrm{k})$;

int $\mathrm{N}=$ getenvif("N", 10000$) ; / /$ 図 2

double $\mathrm{P}=$ getenvif("P", 0.001$)$;

RandPerm perm(sz); // 図 5

double o[sz]，e[sz]；// 観測数，期待值

/ / 観測数を 0 初期化, 期待値を計算

for ( int $i=0 ; i<s z ; i++$ ) \{

$\circ[i]=0$;

e $[i]=N * 1.0 / \mathrm{sz}$;

順列を $\mathrm{N}$ 回生成

for ( int $i=0 ; i<N$; $i++$ ) \{

vector $<$ int $>$ vec $=$ perm.generate () ;

/順列の性質を満たしていることを確認

BOOST_CHECK_EQUAL ( vec.size(), sz) ;

for ( int $j=1 ; j<=s z ; j++$ )

BOOST_CHECK( find(vec.begin(), $\operatorname{vec} . \operatorname{end}(), j) !=\operatorname{vec} . \operatorname{end}())$;

$/ / \mathrm{k}$ 番目の観測をカウント

o[ $\operatorname{vec}[k]-1]+=1.0$;

\}

/ / x^2 統計量を計算

double chisq $=0$;

for ( int $i=0 ; i<s z ; i++)$

chisq $+=(o[i]-e[i]) *(o[i]-e[i]) / e[i]$;

/ / x^2 分布で片側検定

boost: : math: :chi_squared_distribution<> chisq_dist ( sz-1);

double ulim = quantile ( chisq_dist, 1-P );

BOOST_CHECK_MESSAGE ( chisq < ulim,

"genparm (" < sz $<$ ", " < k < ") 分布異常 "

<< "正しいプログラムがこの分布を出す確率"

$<$ cdf ( complement ( chisq_dist, chisq) )

$<$ "は, 有意水準" $<$ P $<<$ "以下です" );

// Boost テストケース: クラスに対する通常のテスト

BOOST_AUTO_TEST_CASE ( Test_PermRand)

RandPerm perm0 (0), perm1 (1);

BOOST_CHECK_EQUAL ( perm0.size (), 0 );

BOOST_CHECK ( permo.generate().empty() );

BOOST_CHECK_EQUAL ( perm1.size(), 1 );

BOOST_CHECK_EQUAL ( perm1.generate ().size (), 1 ); BOOST_CHECK_EQUAL ( perm1.generate () [0], 1);

// Boost テストケース: 分布のテスト

BOOST_AUTO_TEST_CASE ( Test_PermRand_Dist )

// テストするパラメータ值のセット

int values [9] [2] $=\{\{2,0\},\{3,0\}$

$\{4,0\},\{2,1\},\{3,1\},\{4,1\},\{3,2\},\{4,2\},\{4,3\}\}$; // タスクを並列実行 (静的分配)

\#pragma omp parallel for schedule (static)

for ( int $i=0 ; i<9$; $i++$ )

TestPerm( values[i][0], values[i][1]);

// main 関数 (テストケースを順に実行)

bool init_test() \{return true; \}

int main( int argc, char *argv[] )

initialize_rand ()； // 乱数の初期化 (図 2)

return boost: :unit_test: :unit_test_main ( \&init_test, argc, argv);

図 6 permtest.cpp: perm.h に対するC++テストコードの例 . 
待分布と有意に異なるとはいえない」，すなわちプログ ラムの間違いは検出できなかったという結論になる .

この方法は, 観測されるものか離散值であれば(たと えば隠れ状態の並び方など，，光のまま適用できるし，指 数分布などの連続値である場合には，区間を適当な $K$ 個 に分割したヒストグラムを求め，理論的なヒストグラム 形状との間でカイ 2 乗検定を実施すればよい . 同じ有意 水準でも，サンプル数か増えれば，より微妙な間違いに 対する検出力は強くなる .

例として , 图 5 で示すサンプリングアルゴリズムに対 するテストプログラムを图 6 に示す ${ }^{* 6}$. 実行すると , テ スト失敗のメッセージが表示されることから，一見正し く見える 図 5 のアルゴリズムは誤った分布を作ること がわかる*7. このような誤りが , 後で樣々なトラブルを 引き起こし, 研究時間を浪費することは想像に難くない． テストによって早期発見することの重要性が窥える.

この例ではサンプルが無相関なので, 通常の検定手法 を光のまま適用できるが, MCMC 法では一般にサンプル 間に相関があるため, 全サンプルを対象に通常のカイ 2 乗検定を実施すると，棄却という結果になることが多い． 相関がなくなるぐらい十分に広い間隔でサンプルを収集 すれば通常の検定が可能であるが，「十分に広い間隔」の 基準が明確でなく，テストに必要な計算時間が不必要に 増大してしまうという問題がある，乥れよりは，混合時 間 $T$ のマルコフ連鎖を使ったモンテカルロ法のサンプル に対してカイ 2 乗統計量を計算すると $\chi^{2} / T$ がカイ 2 乗 分布に従う性質を利用するほうがよい，一般に混合時間 $T$ を知ることは難しいが, 10000 個程度の少ないサンプ ル数に対する $\chi^{2}$ 統計量から $T$ の上限として適当な定数 を見積もり，サンプル数を増やしても傾向か変わらない かどうかを調べることができる.一方, 分布が間違って いる場合には,サンプル数を増やせば増やすほど $\chi^{2}$ 統計 量の值が増加していくことから，区別が可能である．あ るサンプリング法とテストデータに対して，いったん正 しいと思えるプログラムができて , 混合時間 $T$ の推定值 が得られたならば，回帰テスト中に光の推定値を埋め込 むことで, 光の後にコードが変更されても, 分布が変化 していないことを確認することが可能となる．

\section{4 詳細釣り合い条件の検査による問題の同定}

上記の方法で , サンプリングしている分布か間違って いるという結論が出た場合でも，どの部分が間違ってい るのかが分からない,という事態は往々にして生じる.特 に , 違いが小さい場合に , 兴の微小な差がプログラムの どの部分から生じるのかの追跡は簡単ではない .

しかし , マルコフ連鎖モンテカルロ (MCMC) 法を利

\footnotetext{
*6 g++ -fopenmp permtest.cpp -lboost_unit_test_ framework-mt -o permtest でコンパイルできる (GCC 4.x 環境で Boost が適切にインストールされている場合) .

*7 正しくは $s$ ! 個の順列から選択されるよう下線部を変更する . int $j=$ (int) floor ( uniform01 ()* (i+1) );
}

用したプログラムであれば, 詳細釣り合い条件の成立を 調べることで，より詳細な問題を同定することができる 場合がある .ここでは，MCMC 法のプログラムに限定 して, 詳細釣り合い条件の検査法を説明する．

MCMC 法を用いた実用的なアルゴリズムのほとんどは 詳細釣り合い条件を満たす一すなわち, 定常分布をサ ンプリングしているのであれば , サンプリング状態 $s_{1}$ か ら状態 $s_{2}$ への遷移確率と状態 $s_{2}$ から状態 $s_{1}$ への遷移確 率が等しくなるよう設計されている.これをプログラム の実行経過から確認するには, 各サンプリング状態 $s$ を カイ 2 乗検定で使った排他的事象の形で表現したうえで， すべてのサンプリング状態の組 $\left(s_{1}, s_{2}\right)$ に対して ,サン プリングの各ステップで $s_{1}$ から $s_{2}$ への状態変化の回数 $n\left(s_{1}, s_{2}\right)$ をカウントし,$n_{1}=n\left(s_{1}, s_{2}\right)$ と $n_{2}=n\left(s_{2}, s_{1}\right)$ が同一の確率分布から出ているかどうかを検定すること になる .これはいわゆる符号検定であるが, 十分なサン プル数があれば (経験的には $n_{1}, n_{2}$ が 10 以上であれば) $Z=\left(\left|n_{1}-n_{2}\right|-1\right) / \sqrt{n_{1}+n_{2}}$ が正規分布で近似できる ことから，両側確率を計算する (分子の -1 はバイアスの 修正である $. n_{1}=n_{2}$ のときは計算不要なのて除外する) . このとき，検定の有意水準 ( $p$ 値) は，状態遷移の組の 多さに応じて事前に決定すべきである．たとえば正しい 分布から得られたデータでも $p$ 值を 0.05 に設定した場 合, 100 組の状態遷移を検定すると 5 回程度は問題が誤 検出されてしまう．筆者らは, 状態遷移の組が数百組程 度のときに, $p$ 值を 0.001 ぐらいに設定して検定してい る. 弚れでも, サンプル数を増やしながら何回かテスト することで, ほとんどの問題は発見できる．また，一か 所の詳細つり合いが崩れていると, 他の場所でも影響さ れて詳細つり合いが崩れることがあることに注意された い.ずれの大きい遷移に対象を絞り，弚の遷移を起こす ときのプログラムの計算過程を詳細に調べることで, 何 らかの原因が見つけられると思われる．

\section{$5 \cdot 5$ 確率モデルに対する理論値の計算}

比較対象となる理論值の計算は, 確率モデル検証にお ける不可欠のステップである . 簡単なモデルであれば， 簡単な表計算ソフトなどを利用した手計算で導出できる。 たとえば，生成的確率モデルであれば，確率的な生成過 程の各ステップを追うことで, すべての可能な隠れ状態 の系列 $z$ と出力の系列 $s$ に対する生成確率の分布 $p(z, s)$ を導出できる . 推論プログラムか計算するのは, 与えら れた出力系列に対する隠れ状態の条件付き分布 $p(z \mid s)$ で あるが, すべての可能性のうちから, 出力が一致する場 合だけを切り出し，合計が1になるよう正規化すること で, 以下のように理論分布が求められる:

$$
p(z \mid s)=\frac{1}{Z} p(z, s), \quad Z=\sum_{z^{\prime}} p\left(z^{\prime}, s\right) .
$$

しかし , infinite HMM のような複雑な確率モデルの場合， 理論値を計算することは簡単ではない，中華料理店過程 


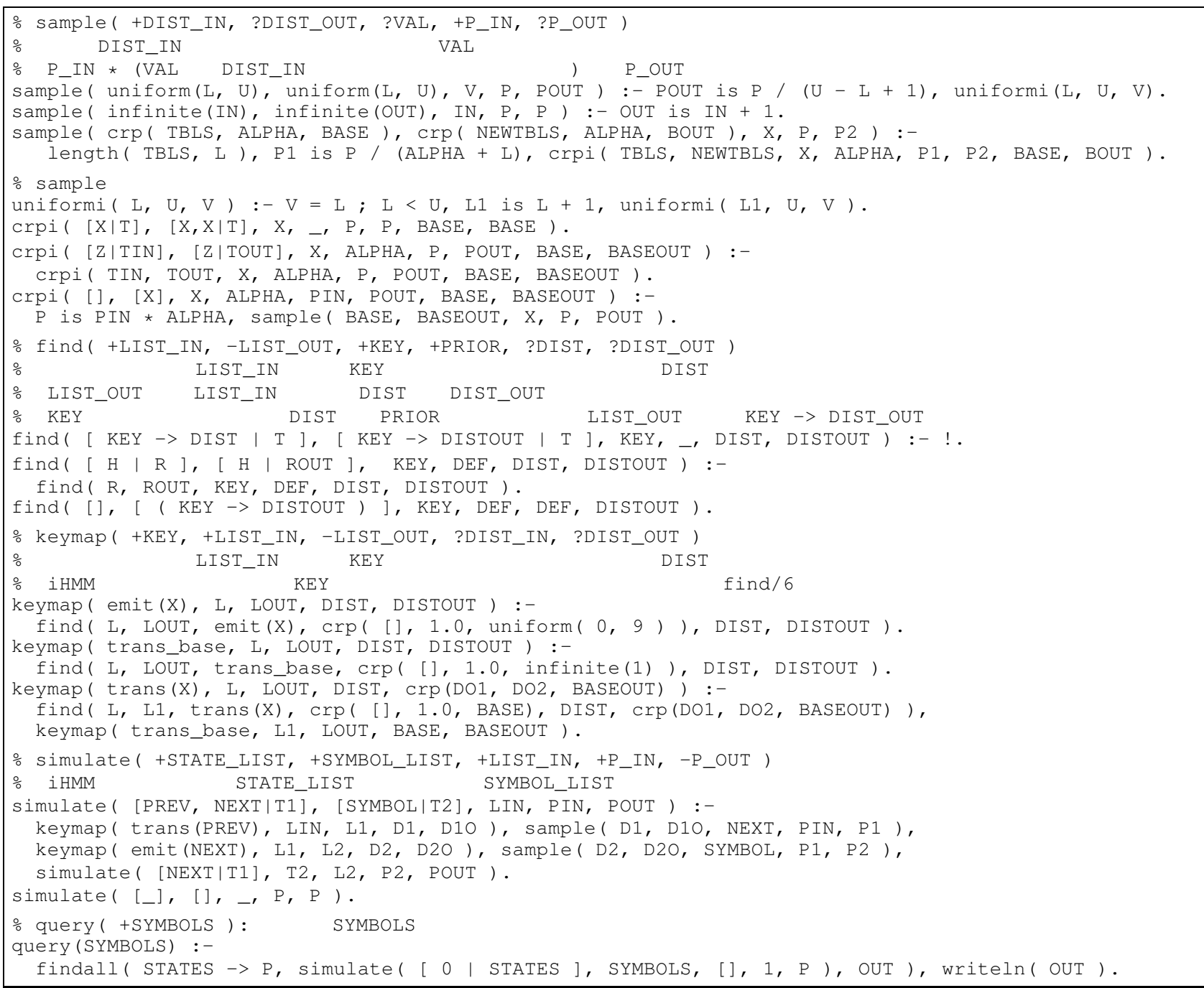

図 7 i hmm.pl: infinite HMM に対応する確率の理論値を計算する Prolog プログラム .

(CRP) [Aldous 85] を階層化した表現を用いることで, 逐 次的な確率過程の形て理論值を計算することは可能だが， 図 4 のような理論值を手計算で導出することは難しい 検査用のデータを小さくすれば簡単になるが, iHMM の プログラムを十分に検証するには, 長さ 4 の出力列が最 低限必要である*8 . 理論值の計算のためにサンプリング プログラム自身を拡張するのは, コードが不必要に複雑 化することから避けるべきである .

ここでは，正確な生成確率を計算するために，別に専用 のプログラムを記述することを提案する。特に，CRPな どの逐次的な確率過程に対しては, Prolog などの論理型 言語を利用することで, すべての場合分けを網羅し, 確率 值を計算することが容易になる．図７は，iHMMに対す る確率計算プログラムの例である . consult (i hmm) . でProlog に読み込ませ, query $([1,2,1,3])$. で, 出 力列 $[1,2,1,3]$ に対応する状態列と確率値の組を列挙する ことができる(簡単のため, 計算の細かい場合分け別の 生成確率 $p(s, z)$ 値を表示させているが，もちろん Prolog

$* 8 \quad$ 長さ 3 以下の出力列ではハイパーパラメータ $\alpha$ か計算結果 に影響しないため $\alpha$ に関わる部分を検証したことにならない .
上で状態列ごとに集計し，值を正規化することも可能で， 図 4 の結果が得られる) .

このような論理型言語を使う手法は, iHMM 以外の確 率モデル (LDA, CRF など) であっても，同樣に有効で あると考えられる、確率発展を節として記述するだけで， すべての可能性と確率值を列挙できる簡便性は, バック トラックが組み込まれている論理型言語ならではの使い 方であろう .

\section{6. む す び}

本稿では, 機械学習分野, 特にサンプリングなどの乱 択アルゴリズムの実装を含む領域の研究においてはプロ グラムの検証が重要となることを論じ，兴の検証の実践 的手法について紹介した .すなわち，質・量ともに十分 なテストコードを記述すること, 問題が再現できるよう 乱数のシード值を制御すること，サンプリング結果を検 証するには出力されたサンプル分布に対して統計的検定 手法を用いること, テストでの比較対象となる理論値の 導出のためにも専用プログラムを開発することである． 
研究に使うプログラムは, 正しく動作していることが 大前提であり，検証を実施したとしても論文には反映さ れないのか現状である . 検証は, いわば，裏方の仕事と 言ってもよい，光れでも，ここで検証の重要性を改めて 説くのは, 弚のようにしてプログラム検証に十分な時間 を割くことで，あとから無駄にする時間が減り，結果的 に早く結果を出せることが多いからである、特に，モン テカルロ法などの乱択アルゴリズムを用いる場合，しっ かりした手法で検証を行わなければ , プログラム中の問 題を見逃す危険性が高い，光して，弚のようにして見逃 された問題が，あとで樣々なトラブルを生み，乥れらの 解決には長い時間を要することになることは，しばしば 経験することである .

もともとは, サンプリングなどの統計的計算手法は主 に統計学の領域で研究されてきており，統計学分野の研 究者はこうした性質のデータに対する検証手法を熟知し ていたため, 問題になることが少なかったのではないか と思われる．しかし，人工知能, 機械学習などの他分野 の研究者が統計的手法を利用するようになってきている にもかかわらず, このような検証の必要性に関する情報 は，十分に与えられていないのか現状である . 本稿のよ うな知識を共有することで, 今後の本研究領域の発展に つながれば幸いである。

\section{謝 辞}

本研究は，総合科学技術会議により制度設計された最 先端研究開発支援プログラム (FIRST 合原最先端数理モ デルプロジェクト) により，日本学術振興会を通して助 成されたものである.また，本研究の一部は科学研究費 補助金 (若手 B)20700126 の助成を受けた . テストが必要 なアルゴリズム例は奥牧人さんの提供である . 吉田康久 さんには草稿に有益なコメントをいただいた .

\section{$\diamond$ 参 考 文 献 $\diamond$}

[Aldous 85] Aldous, D.: Exchangeability and related topics, in École d'été de Probabilités de Saint-Flour XIII-1983, Lecture notes in mathematics 1117, pp. 1-198, Springer Verlag (1985)

[Beal 02] Beal, M. J., Ghahramani, Z., and Rasmussen, C. E.: The Infinite Hidden Markov Model, in Advances in Neural Information Processing Systems, Vol. 14, pp. 577-584, MIT Press (2002)

[Beck 02] Beck, K.: Test Driven Development: By Example, Addison-Wesley (2002), 邦訳『テスト駆動開発入門』(長瀬 嘉秀 (監訳), ピアソンエデュケーション, 2003)

[Beizer 95] Beizer, B.: Black-Box Testing: Techniques for Functional Testing of Software and Systems, Wiley, NY (1995)

[Bishop 07] Bishop, C. M.: Pattern Recognition and Machine Learning, Springer (2007), 邦訳『パターン認識と機械学習上/下 - ベ イズ理論による統計的予測』(元田 浩ほか (訳), 丸善出版, 2007)

[Blei 03] Blei, D. M., Ng, A. Y., and Jordan, M. I.: Latent Dirichlet Allocation, Journal of Machine Learning Research, Vol. 3, No. 4-5, pp. 993-1022 (2003)

[Chelimsky 10] Chelimsky, D., Astels, D., et al.: The RSpec Book: Behaviour Driven Development with Rspec, Cucumber, and Friends, Pragmatic Bookshelf (2010), 邦訳『The RSpec Book』(角谷 信太 郎, 豊田祐司 (監修), 翔泳社, 2012)
[Engström 10] Engström, E., Runeson, P., and Skoglund, M.: A systematic review on regression test selection techniques, Inf. Softw. Technol., Vol. 52, No. 1, pp. 14-30 (2010)

[Feathers 04] Feathers, M.: Working Effectively With Legacy Code, Prentice Hall, NJ (2004), 邦訳『レガシーコード改善ガイド』(平 澤章 (か (訳), 翔泳社, 2009)

[Haramoto 08] Haramoto, H., Matsumoto, M., Nishimura, T., Panneton, F., and L'Ecuyer, P.: Efficient Jump Ahead for F2-Linear Random Number Generators, INFORMS Journal on Computing, Vol. 20, No. 3, pp. 385-390 (2008)

[Hjort 10] Hjort, N. L., Holmes, C., Müller, P., and Walker, S. G. eds.: Bayesian Nonparametrics, Cambridge Series in Statistical and Probabilistic Mathematics, Cambridge University Press (2010)

[Hoare 69] Hoare, C. A. R.: An axiomatic basis for computer programming, Comm. ACM, Vol. 12, No. 10, pp. 576-583 (1969)

[伊庭 05] 伊庭 幸人, 種村 正美, 大森 裕浩, 和合 肇, 佐藤整尚, 高 橋 昭彦 : 計算統計 II マルコフ連鎖モンテカルロ法と产の周辺, 統計科学のフロンティア, 第 12 巻, 岩波書店 (2005)

[Koskela 12] Koskela, L.: Unit Testing in Java, Manning (2012), ebook provided in early access program

[Mascagni 00] Mascagni, M. and Srinivasan, A.: SPRNG: A Scalable Library for Pseudorandom Number Generation, ACM Transactions on Mathematical Software, Vol. 26, pp. 436-461 (2000)

[McKim 01] McKim, R. and Mitchell, J.: Design by Contract, by Example, Addison-Wesley (2001)

[Meyer 91] Meyer, B.: Eiffel: The Language, Prentice Hall ObjectOriented Series, Prentice Hall, NJ (1991)

[Myers 11] Myers, G. J., Badgett, T., and Sandler, C.: The Art of Software testing, third edition, Wiley (2011), 邦訳は旧版『ソフトウェ ア・テストの技法第 2 版』(長尾 真 ほか (訳), 近代科学社, 2006)

[Panzl 78] Panzl, D. J.: Automatic Software Test Drivers, Computer, Vol. 11, No. 4, pp. 44-50 (1978)

[Rogers 01] Rogers, W. P.: J2SE 1.4 premieres Java's assertion capabilities, JavaWorld http://www.javaworld.com/ javaworld/jw-11-2001/jw-1109-assert.html (2001)

[Spinellis 05] Spinellis, D.: Version control systems, IEEE Software, Vol. 22, No. 5, pp. 108-109 (2005)

[Teh 06a] Teh, Y. W.: A Bayesian Interpretation of Interpolated Kneser-Ney, Technical Report Technical Report TRA2/06, School of Computing, NUS (2006)

[Teh 06b] Teh, Y. W., Jordan, M. I., Beal, M. J., and Blei, D. M.: Hierarchical Dirichlet Processes, Journal of the American Statistical Association, Vol. 101, No. 476, pp. 1566-1581 (2006)

[東京 92] 東京大学教養学部統計学教室 (編) : 自然科学の統計学, 東京大学出版会 (1992)

〔担当委員 : 山川 宏〕

2011 年 7 月 1 日 受理

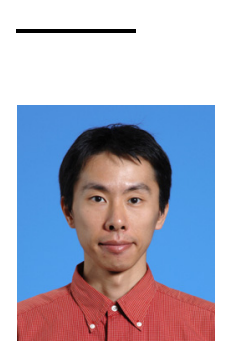

者 紹 介

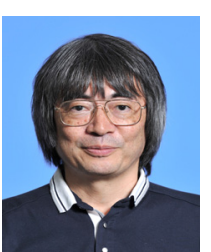

\section{牧野 貴樹(正会員)}

2002 年 東京大学大学院理学系研究科情報科学専攻博士 課程修了. 博士 (理学) . 2005 年-2011 年, 東京大学総括 プロジェクト機構領域創成/学術統合化プロジェクト研究 部門学術統合化プロジェクト(ヒ上)特任助教.2011 年上 り東京大学生産技術研究所最先端数理モデル連携研究也 ンター特任准教授、機械学習, コミュニケーション数理モ デルの研究に従事

\section{合原 一幸}

1982 年東京大学 大学院工学系研究科電子工学専攻博士 課程修了. 工学博士. 1993 年 東京大学工学部計数工学 科助教授. 1998 年東京大学 大学院工学系研究科計数工 学専攻教授. 1999 年東京大学 大学院新領域創成科学研 究科複雑理工学専攻教授. 2003 年東京大学生産技術研 究所 教授. 